\title{
Autologous Mixed Lymphocyte Reaction in Patients with Hodgkin's Disease
}

\author{
EVIDENCE FOR A T CELL DEFECT
}

\author{
Edgar G. Engleman, Claudia J. Benike, Richard T. Hoppe, Henry S. Kaplan, \\ and F. RALPH BERBERICH, Departments of Pathology, Radiology, and Pediatrics, \\ Stanford University School of Medicine, Stanford, California 94305
}

\begin{abstract}
A B S T R A C T The proliferative response of T lymphocytes cultured with autologous non-T lymphocytes is known as the autologous mixed lymphocyte reaction (MLR). This reaction can be demonstrated reproducibly in healthy individuals and has been shown to generate specific cytotoxic $T$ cells, as well as $T$ cells that regulate antibody synthesis and cell-mediated immunity. In this study, we demonstrate that the autologous MLR is impaired or absent in most patients with Hodgkin's disease regardless of age, sex, pathologic stage, or histologic classification. In 64 patients, the mean autologous MLR was $3,084 \pm 1,878 \mathrm{cpm}$ compared to $16,552 \pm 6,532$ in 29 healthy donors. A defect in autologous MLR was observed in newly diagnosed patients before the initiation of therapy, but was also found in patients without evidence of recurrent disease up to $15 \mathrm{yr}$ after treatment.
\end{abstract}

These findings could not be explained by abnormal kinetics or poor viability of stimulator or responder cells. The possibility that suppressor cells are responsible for the reduction of $T$ cell autoreactivity was examined by comparing the autologous MLR of a healthy HLA-identical sibling in the presence and absence of $T$ or non- $T$ cells of an affected sibling. No inhibitory effects were observed. Similarly, substitution of patient plasma for pooled $A B$ serum failed to inhibit the autologous responses of normal donors. Increasing the number of responder $T$ cells in the culture or removing adherent cells from the stimulator population enhanced autoreactivity in some patients, indicating that the defect is not absolute. In two families, $T$ cells of healthy HLA-A, B, and DR-identical siblings of patients responded normally to the non-T cells of their affected siblings, whereas patients' $T$ cells failed to respond both to their own stimulator cells and those

Received for publication 11 February 1980 and in revised form 24 March 1980. of their healthy HLA-identical siblings. These data indicate that the impairment of autologous MLR in some patients is due to a reduction or dysfunction of responder $T$ cell activity and not to a defect of autologous stimulator cells.

\section{INTRODUCTION}

The immunologic status of patients with Hodgkin's disease has been a topic of intensive investigation for the past two decades. Although antibody responses appear to be unimpaired $(1,2)$, patients frequently exhibit defects of $T$ cell-mediated immune functions manifested by diminished delayed hypersensitivity responses (3-7), impaired ability to reject skin allografts $(8-10)$, and decreased resistance to certain types of infection (11-12). Several in vitro functions of peripheral blood $\mathrm{T}$ cells have been shown to be impaired, including the blastogenic response to soluble antigens (13-15), alloantigens $(16,17)$, and plant lectins $(2$, 18-28). Some of these defects may be explained by the presence of suppressor monocytes $(17,28-30)$ and suppressor $T$ cells $(29,31)$. Although these abnormalities are of variable magnitude and are not diagnostic of Hodgkin's disease, their frequent occurrence in patients with this malignancy suggests that a defect of cell-mediated immunity may play a role in the pathogenesis of the disease.

In this study, the autologous mixed lymphocyte reaction (MLR) ${ }^{1}$ is assessed in patients with Hodgkin's disease. The autologous MLR is the proliferative response of $\mathrm{T}$ lymphocytes when cultured with autologous non-T lymphocytes $(32,33)$. The significance of this reaction in vivo is not known, and it is not es-

\footnotetext{
${ }^{1}$ Abbreviations used in this paper: FCS-PBS, fetal calf serum in phosphate-buffered saline; MLR, mixed lymphocyte reaction; PBML, peripheral blood mononuclear leukocytes; TNI, total nodal irradiation.
} 
TABLE I

Clinical Characteristics and Autologous and Allogeneic MLR in Patients with Hodgkin's Disease

\begin{tabular}{|c|c|c|c|c|c|c|c|c|}
\hline \multirow[b]{2}{*}{$\begin{array}{l}\text { Case } \\
\text { No. }\end{array}$} & \multirow[b]{2}{*}{ Age } & \multirow[b]{2}{*}{ Sex } & \multirow[b]{2}{*}{$\begin{array}{l}\text { Pathologic } \\
\text { stage }\end{array}$} & \multicolumn{3}{|c|}{ Clinical characteristics } & \multicolumn{2}{|c|}{$\left[{ }^{3} \mathrm{H}\right]$ Thymidine incorporation } \\
\hline & & & & Histology & $\begin{array}{c}\text { Prior } \\
\text { therapy }\end{array}$ & $\begin{array}{l}\text { Last } \\
\text { therapy }\end{array}$ & $\begin{array}{l}\text { Autologous } \\
\text { MLR }\end{array}$ & $\begin{array}{l}\text { Allogeneic } \\
\text { MLR }\end{array}$ \\
\hline & & & & & & $y r$ & & \\
\hline \multicolumn{9}{|c|}{ Active disease untreated } \\
\hline 1 & 18 & $\mathrm{~F}$ & II A & NS & - & - & 2,411 & 42,143 \\
\hline 2 & 26 & F & II A & NS & - & - & 6,971 & 36,530 \\
\hline 3 & 26 & F & II A & NS & - & - & 844 & 62,046 \\
\hline 4 & 44 & $\mathbf{M}$ & IV B & $\mathrm{MC}$ & - & - & 241 & 12,070 \\
\hline 5 & 15 & $\mathbf{F}$ & II A & NS & - & - & 963 & 7,145 \\
\hline 6 & 31 & $\mathbf{M}$ & IV A & NS & - & - & 3,241 & 67,884 \\
\hline 7 & 34 & M & II A & NS & - & - & 1,063 & 22,155 \\
\hline 8 & 26 & $\mathbf{M}$ & II A & NS & - & - & 881 & 12,617 \\
\hline 9 & 13 & $\mathrm{~F}$ & II A & UN & - & - & 564 & 41,806 \\
\hline 10 & 6 & $\mathbf{M}$ & III A & NS & - & - & 7,179 & 25,989 \\
\hline Mean & & & & & & & $2,436 \pm 1,660$ & $33,039 \pm 14,556$ \\
\hline \multicolumn{9}{|c|}{$\begin{array}{l}\text { Treatment completed } \\
\text { no evidence of disease }\end{array}$} \\
\hline 11 & 12 & $\mathbf{F}$ & III B & UN & ST & 10 & 937 & 31,652 \\
\hline 12 & 15 & $\mathbf{M}$ & I A & NS & TNI & 8 & 4,585 & 36,454 \\
\hline 13 & 47 & $\mathbf{F}$ & II A & NS & $\mathrm{IF}+\mathrm{MOP}$ & 3 & 1,507 & 5,260 \\
\hline 14 & 50 & $\mathbf{M}$ & II A & $\mathrm{MC}$ & ST & 4 & 537 & 13,590 \\
\hline 15 & 23 & $\mathbf{M}$ & II A & $\mathrm{MC}$ & TNI + PAVe & 1 & 229 & 6,392 \\
\hline 16 & 24 & $\mathrm{~F}$ & IV B & NS & $\mathrm{TNI}+\mathrm{MOP}$ & 6 & 664 & 13,300 \\
\hline 17 & 35 & $\mathbf{M}$ & III A & NS & TNI + PAVe & 2 & 672 & 6,366 \\
\hline 18 & 16 & $\mathbf{F}$ & II A & NS & ST & 5 & 716 & 40,946 \\
\hline 19 & 52 & $\mathbf{M}$ & II A & NS & ST & 1 & 546 & 18,543 \\
\hline 20 & 55 & $\mathbf{M}$ & IV A & NS & $\mathrm{TNI}+\mathrm{MOP}$ & 4 & 2,449 & 69,441 \\
\hline 21 & 27 & $\mathbf{M}$ & III B & MC & $\mathrm{TNI}+\mathrm{MOP}$ & 1 & 1,052 & 6,692 \\
\hline 22 & 54 & $\mathrm{~F}$ & II A & UN & IF & 11 & 12,569 & 28,248 \\
\hline 23 & 21 & $\mathbf{M}$ & II A & NS & $\mathrm{ST}+\mathrm{MOP}$ & 5 & 2,988 & 19,244 \\
\hline 24 & 34 & $\mathrm{~F}$ & II B & NS & TNI & 7 & 2,743 & 16,088 \\
\hline 25 & 20 & $\mathbf{F}$ & II B & NS & TNI & 9 & 340 & 3,092 \\
\hline 26 & 31 & $\mathbf{M}$ & III B & NS & TNI + PAVe & 3 & 519 & 18,018 \\
\hline 27 & 49 & $\mathbf{F}$ & III A & MC & $\mathrm{TNI}+\mathrm{MOP}$ & 7 & 1,449 & 30,516 \\
\hline 28 & 22 & $\mathbf{M}$ & III A & MC & TNI & 5 & 239 & 10,222 \\
\hline 29 & 31 & $\mathbf{M}$ & I A & LP & $\mathrm{IF}+\mathrm{MOP}$ & 1 & 546 & 3,569 \\
\hline 30 & 21 & $\mathbf{F}$ & I A & NS & $\mathrm{IF}+\mathrm{MOP}$ & 7 & 3,826 & 43,015 \\
\hline 31 & 25 & $\mathbf{F}$ & II A & UN & ST & 12 & 1,609 & 38,020 \\
\hline 32 & 33 & $\mathbf{M}$ & III B & NS & $\mathrm{TNI}+\mathrm{MOP}$ & 1 & 1,007 & 25,811 \\
\hline 33 & 53 & $\mathbf{M}$ & II A & LP & TNI & 8 & 1,436 & 23,055 \\
\hline 34 & 55 & $\mathbf{M}$ & I A & MC & IF + MOP & 4 & 2,213 & 27,578 \\
\hline 35 & 25 & $\mathbf{M}$ & III A & NS & TNI + MOP & 6 & 6,854 & 49,241 \\
\hline 36 & 42 & F & II A & NS & ST & 1 & 1,845 & 21,598 \\
\hline 37 & 26 & F & III B & NS & TNF + MOP & 3 & 1,925 & 39,856 \\
\hline 38 & 24 & $\mathrm{~F}$ & I A & $\mathrm{MC}$ & IF & 15 & 5,470 & 25,425 \\
\hline 39 & 31 & $\mathbf{M}$ & I A & NS & IF & 16 & 14,065 & 29,330 \\
\hline 40 & 22 & F & II $\mathbf{A}$ & NS & ST & 9 & 3,840 & 28,955 \\
\hline 41 & 23 & $\mathbf{M}$ & I B & NS & TNI & 7 & 1,996 & 3,693 \\
\hline 42 & 21 & F & II B & NS & $\mathrm{TNI}+\mathrm{MOP}$ & 6 & 2,924 & 10,047 \\
\hline 43 & 32 & $\mathrm{~F}$ & III A & MC & TNI + MOP & 2 & 975 & 3,450 \\
\hline 44 & 17 & $\mathrm{~F}$ & II A & NS & $\mathrm{IF}+\mathrm{MOP}$ & 3 & 259 & 15,862 \\
\hline 45 & 16 & $\mathbf{M}$ & II A & NS & $\mathrm{ST}+\mathrm{PAVe}$ & 4 & 5,593 & 34,958 \\
\hline 46 & 21 & $\mathrm{~F}$ & III A & NS & $\mathrm{TNI}+\mathrm{MOP}$ & 5 & 1,225 & 20,332 \\
\hline 47 & 24 & $\mathbf{F}$ & IV B & NS & $\mathrm{TNI}+\mathrm{MOP}$ & 6 & 3,250 & 29,706 \\
\hline
\end{tabular}


TABLE I (Continued)

\begin{tabular}{|c|c|c|c|c|c|c|c|c|}
\hline $\begin{array}{l}\text { Case } \\
\text { No. }\end{array}$ & Age & Sex & $\begin{array}{l}\text { Pathologic } \\
\text { stage }\end{array}$ & \multicolumn{3}{|c|}{ Clinical characteristics } & \multicolumn{2}{|c|}{$\left[{ }^{3} \mathrm{H}\right]$ Thymidine incorporation } \\
\hline & & & & & & $y r$ & \multicolumn{2}{|c|}{$c p m$} \\
\hline 48 & 19 & $\mathbf{F}$ & II A & $\mathbf{U N}$ & IF & 11 & 17,019 & 41,844 \\
\hline 49 & 30 & $\mathbf{F}$ & II B & NS & $\mathrm{TNI}+\mathrm{MOP}$ & 3 & 2,416 & 22,639 \\
\hline 52 & 34 & $\mathbf{F}$ & II B & NS & TNI & 8 & 1,196 & 25,356 \\
\hline 53 & 15 & $\mathbf{M}$ & II B & NS & $\mathrm{TNI}+\mathrm{MOP}$ & 2 & 1,616 & 15,386 \\
\hline 54 & 27 & $\mathrm{M}$ & III A & NS & $\begin{array}{l}\text { TNI + MOP } \\
\text { PAVe }\end{array}$ & 2 & 629 & 34,348 \\
\hline 55 & 18 & $\mathbf{M}$ & I B & UN & TNI & 11 & 2,908 & 6,903 \\
\hline 60 & 46 & $\mathbf{M}$ & III A & NS & $\mathrm{TNI}+\mathrm{MOP}$ & 2 & 6,556 & 53,462 \\
\hline 61 & 33 & $\mathbf{M}$ & III B & NS & $\mathrm{TNI}+\mathrm{MOP}$ & 3 & 16,651 & 24,748 \\
\hline 62 & 27 & $\mathbf{M}$ & III B & NS & $\mathrm{TNI}+\mathrm{MOP}$ & 1 & 992 & 1,487 \\
\hline 63 & 27 & $\mathbf{F}$ & III A & NS & $\mathrm{TNI}+\mathrm{MOP}$ & 8 & 5,862 & 26,073 \\
\hline 64 & 25 & $\mathbf{F}$ & IV B & NS & $\mathrm{TNI}+\mathrm{MOP}$ & 3 & 2,620 & 5,000 \\
\hline Mean & & & & & & & $3,494 \pm 1,920$ & $24,074 \pm 12,611$ \\
\hline
\end{tabular}

Abbreviations used in this table: NS, nodular sclerosis; MC, mixed cellularity; LP, lymphocyte predominance; UN, unclassified; PAVe, procarbazine, 1-phenylalanine mustard, vinblastine; MOP, nitrogen mustard, vincristine, procarbazine, with or without prednisone; ST, subtotal irradiation; IF, involved field irradiation.

tablished whether the responding and stimulating cells are distinct from those involved in the allogeneic MLR. The stimulator cells, for example, have been variably reported as B cells (33), null cells (34), and monocytes (35). Despite these uncertainties, there is great interest in the autologous MLR because the reaction can be demonstrated reproducibly in healthy individuals and exhibits immunologic memory and specificity (36). The autologous MLR has been shown to provide a proliferative stimulus for the generation of cytotoxic lymphocytes (37), and there is evidence that the autologous MLR influences a variety of immunologic functions, such as production of antibody by $B$ cells $(38,39)$ and responses to mitogenic and allogenic stimuli by $\mathrm{T}$ cells $(40,41)$.

The data to be presented demonstrate that the autologous MLR is markedly diminished in almost all patients studied. The absence of this reaction appears to be due to a defective $T$ responder population rather than to impaired stimulation by the non-T population. The possible relationship of this profound $T$ cell defect to the pathogenesis of Hodgkin's disease is discussed.

\section{METHODS}

Patient population. 64 patients with Hodgkin's disease were studied. All patients had a review of diagnostic biopsy material and underwent lymphangiography and staging laparotomy at Stanford University Hospital. They were treated subsequently and followed in the Stanford University Radiation Therapy Clinic. 10 patients were studied at the time of diagnosis before initiation of treatment. The remainder were studied 1-16 yr after cessation of local, involved field, subtotal or total lymphoid irradiation with or without chemotherapy. These patients were in remission at the time of study. Additional details regarding histologic subclassification, pathologic stage, treatment, and duration of disease are provided in Table $I$.

Cell isolation. Peripheral blood mononuclear leukocytes (PBML) were obtained by Ficoll-Hypaque (Ficoll, Sigma Chemical Co., St. Louis, Mo.; Hypaque, Winthrop Laboratories, New York) gradient centrifugation (42) of fresh heparinized blood. Unless otherwise indicated, T lymphocytes were separated from non-T cells (B cells, monocytes, and null cells) on the basis of rosetting with sheep erythrocytes as described (43). Briefly, $5 \times 10^{6} \mathrm{cells} / \mathrm{ml}$ were suspended in $40 \%$ fetal calf serum in phosphate-buffered saline (FCS-PBS) and mixed with an equal volume of $3 \%$ sheep erythrocytes in $40 \%$ FCS-PBS. This mixture was immediately sedimented over a second Ficoll-Hypaque gradient to separate the rosetted cells ( $E$ rosettes) from the nonrosetted cells. Nonrosetting fractions were further purified by a repeated rosette formation and subsequent density gradient sedimentation. Cells recovered from the rosetted pellet by treatment with $0.155 \mathrm{M} \mathrm{NH}_{4} \mathrm{Cl}$ were $96-99 \% \mathrm{E}$ rosette positive and contained $0-3 \%$ surface immunoglobulin (Ig)-positive cells based on a direct fluoresceinated antibody binding assay (44) and $0-2 \%$ monocytes on the basis of staining with alphanaphthyl acetate (45). Non-T fractions contained $38-66 \%$ 
surface Ig-positive cells, 35-57\% monocytes, and 0-2\% T cells. Where indicated in the text, adherent cells were removed from the non-T population by incubation in $100 \times 25$ mm polystyrene petri dishes (Lab-Tek Div., Miles Laboratories, Naperville, Ill.). After $1 \mathrm{~h}$ at $37^{\circ} \mathrm{C}$ in RPMI $1640 \mathrm{me}-$ dium, nonadherent cells were gently aspirated; of these cells $3-11 \%$ were monocytes.

Alternatively, B cells were separated from $T$ cells on the basis of binding to plastic petri dishes coated with anti-human Ig (46). In this technique $3 \times 10^{7} \mathrm{PBML}$ in $3 \mathrm{ml} \mathrm{5 \%} \mathrm{FCS-PBS}$ were incubated for $70 \mathrm{~min}$ at room temperature in a $100 \times 25$ mm polystyrene petri dish (Lab-Tek Div.) coated with $\mathrm{F}(\mathrm{ab})_{2}{ }^{\prime}$ goat anti-human Ig (N. L. Cappel Laboratories Inc., Cochranville, $\mathrm{Pa}$.). Unbound cells were decanted, and the dish was gently flushed five times with $10 \mathrm{ml}$ of $1 \%$ FCS-PBS. Bound cells were recovered by filling the dish with $25 \mathrm{ml} 1 \%$ FCSPBS and pipetting vigorously. Unbound cells consisted of $91-95 \%$ rosette-positive cells and fewer than $2 \%$ surface Igpositive cells and monocytes. Bound cells recovered after vigorous pipetting consisted of $86-91 \%$ surface Ig-positive cells, 4-9\% monocytes, and 1-6\% $\mathrm{E}$ rosette-positive cells.

Allogeneic and autologous MLR. Subjects were tested against three unrelated donors in allogeneic MLR. In each reaction 50,000 $\mathrm{T}$ cells were cultured with 50,000 irradiated (3,000 rad) allogeneic PBML in $0.2 \mathrm{ml}$ RPMI 1640 medium (Microbiological Associates, Walkersville, Md.) supplemented with $10 \%$ heat-inactivated pooled human $\mathrm{A}$ and $\mathrm{AB}$ serum, $2 \mathrm{mM}$ glutamine, $25 \mathrm{mM}$ Hepes buffer, $100 \mathrm{U} / \mathrm{ml}$ penicillin, and $100 \mu \mathrm{g} / \mathrm{ml}$ streptomycin. For each combination of responder and stimulator cells, triplicate cultures were carried out in round bottomed microtiter plates (Linbro Chemical Co., Hamden, Conn.) in $10 \% \mathrm{CO}_{2}$ at $37^{\circ} \mathrm{C}$. On the 6th $\mathrm{d}$ of culture $\left[{ }^{3} \mathrm{H}\right]$ thymidine (New England Nuclear, Boston, Mass.) was added, $1 \mu \mathrm{Ci} /$ well, and the cultures were harvested $18 \mathrm{~h}$ later. Autologous MLR were performed in an identical manner except that 100,000 irradiated autologous non- $T$ cells were used as stimulators.

Suppressor assays. To determine if cells suppressive of the autologous MLR were present, 50,000 T or non-T cells from a patient were cocultured in the autologous MLR of a healthy HLA-A, B, C, and DR-identical sibling.

\section{RESULTS}

Autologous and allogeneic MLR in normal volunteers and patients. T cells from normal volunteers and patients with Hodgkin's disease were cultured with either irradiated autologous non-T cells or irradiated allogeneic PBML, and proliferation was measured after $1 \mathrm{wk}$ (Fig. 1). The mean autologous MLR of 29 normal subjects was $16,552 \pm 6,532 \mathrm{cpm}$ above background (background range; 156-1,878 cpm). By comparison, the autologous MLR of 64 patients averaged only 3,084 $\pm 1,878 \mathrm{cpm}$ (background range, 96-922 cpm, $P$ $<0.00001$ ). Although the results obtained for each patient are represented only once in Fig. 1, several patients were tested on multiple occasions (up to four times) over a 2-yr period and the results were unchanged. The response of $T$ cells to allogeneic lymphocytes was also diminished in patients $(25,190 \pm 9,814)$ when compared to normals $(37,218 \pm 12,675, P<0.01)$. However, the reduction of allogeneic MLR is modest as compared to the impairment of the autologous MLR, and many patients with vigorous responses to allo-

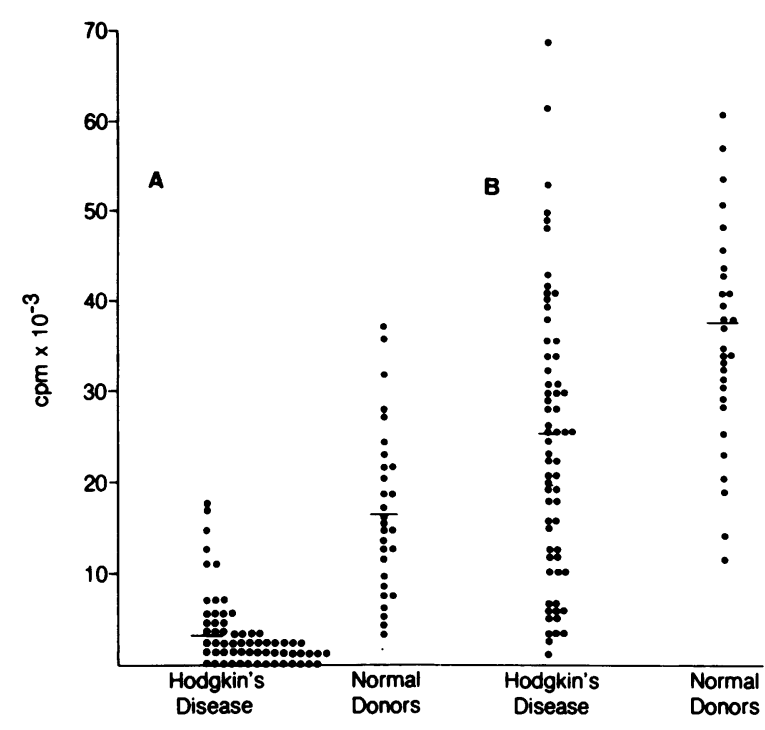

FIGURE 1 Autologous and allogeneic MLR in 64 patients with Hodgkin's disease and 29 healthy donors. $5 \times 10^{4} \mathrm{~T}$ cells were incubated with $1 \times 10^{5}$ autologous non-T cells or $5 \times 10^{4}$ allogeneic PBML from three different healthy donors. Results of the autologous MLR (A) are expressed as the mean of triplicate cultures. Results of allogeneic MLR (B) are expressed as the mean response to three unrelated allogeneic stimulator cells.

geneic lymphocytes failed to respond to autologous non-T cells.

In Table I, the results of autologous and allogeneic MLR are correlated with the clinical characteristics of the patients. There was no relationship between the level of autologous MLR and histologic classification, pathologic stage, or type of therapy. Treated patients in remission for $1-15 \mathrm{yr}$, as well as untreated patients with active disease, had impaired autologous MLR. However, the autologous 'MLR was more markedly depressed in recently treated patients than in patients who had been in remission for several years. For example, only 1 of 12 patients studied within $2 \mathrm{yr}$ of treatment had an autologous MLR $>2,000 \mathrm{cpm}$ compared to 14 of 23 patients tested 6 yr or more after treatment, and 3 of 7 patients studied $10 \mathrm{yr}$ or more after treatment had autologous MLR $>10,000 \mathrm{cpm}$.

Several factors were considered and ruled out as explanations for the impaired autologous MLR in Hodgkin's patients. Greater sensitivity of stimulator cells to X-irradiation was a possibility, but responses to unirradiated stimulator cells were no greater than responses to irradiated stimulator cells. Responder and stimulator cell viability, as assessed by trypan blue exclusion, was always $>95 \%$ at the beginning of experiments. When cultured alone, responder and X-irradiated stimulator cells from Hodgkin's patients retained their viability $(70-80 \%$ after $3 \mathrm{~d})$ to the same extent as cells from normal individuals. In addition, the results 
obtained by measuring incorporation of $\left[{ }^{3} \mathrm{H}\right]$ thymidine were paralleled by the number of blast cells counted microscopically, excluding incongruent blastogenesis and thymidine uptake. On the basis of these initial observations, more extensive experiments were performed in an effort to explain the failure of autologous MLR in these patients.

Effects of altering the time of incubation on the autologous MLR. Although Hodgkin's patients had reduced autologous MLR when measured at $7 \mathrm{~d}$ of incubation, the possibility existed that shorter or longer incubation might reveal significantly greater responses. To examine this possibility, autologous MLR were begun on day 0 and harvested on days $2,4,6,8,10$, and 12. Typical results are shown in Fig. 2. There was no evidence of accelerated or delayed responses in any of 10 patients tested (including 3 with untreated disease), indicating that the defective autologous MLR of these patients cannot be explained by altered kinetics.

Effects of increasing the number of autologous responder and stimulator cells. Studies were performed to determine whether the diminished autologous MLR in patients could be augmented by increasing the number of stimulator or responder cells. As shown in Fig. 3A, the responses of four healthy volunteers increased as the number of responder cells was increased. The responses of three of four Hodgkin's patients (Fig. 3B) also increased as a function of the responder cell number, but remained consistently

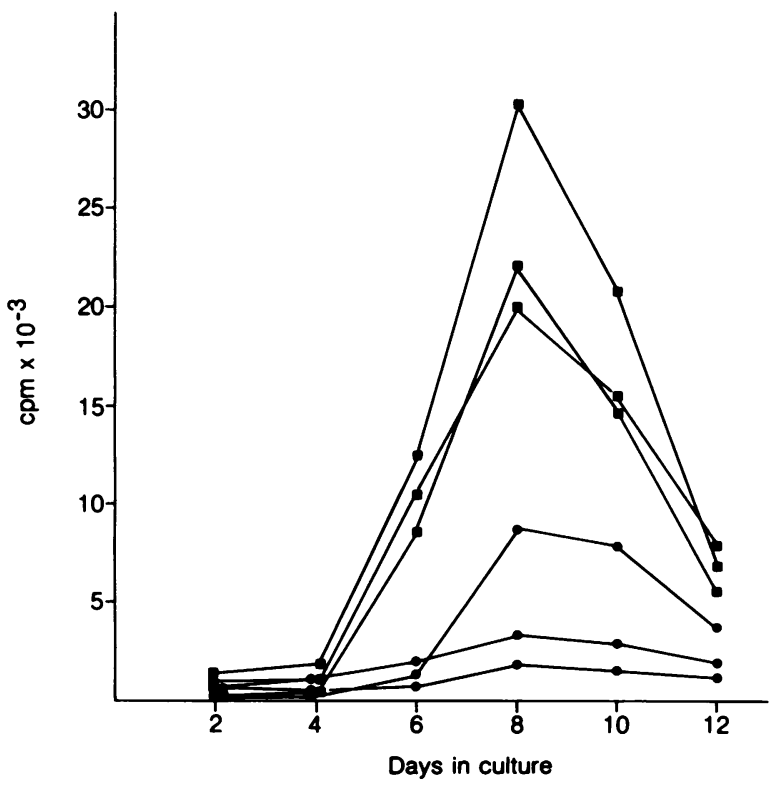

FIGURE 2 Kinetics of autologous MLR in patients with Hodgkin's disease and healthy donors. Cultures between $5 \times 10^{4}$ $T$ cells and $1 \times 10^{5}$ autologous non- $T$ cells from patients with Hodgkin's disease (- -0$)$ and healthy donors ( $\square$ ) were begun on day 0 and harvested on days 2,4 , $6,8,10$, and 12 . The results are the mean of triplicate cultures.
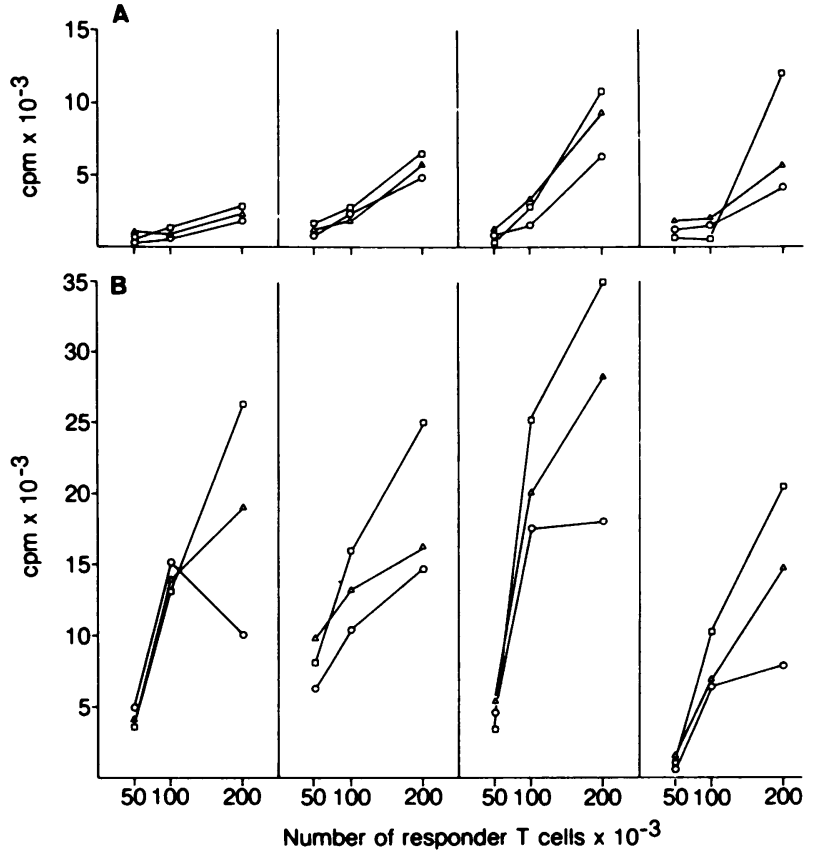

FIGURE 3 Effect of the number of responder and stimulator cells on the autologous MLR. Autologous MLR were performed between varying numbers of responder $\mathrm{T}$ cells, as indicated along the horizontal axis, and $5 \times 10^{4}(\mathrm{O}-\mathrm{O})$, $1 \times 10^{5}(\triangle-\triangle)$, or $2 \times 10^{5}(\square-\square)$ autologous non- $T$ cells. Results in Hodgkin's patients $(A)$ and in normal donors (B) are shown.

lower than the responses of normals at all concentrations tested. When the number of stimulator cells was increased in the presence of a constant number of responder cells, the responses of all four normal volunteers increased, whereas the responses of Hodgkin's patients failed to increase or increased only slightly. Therefore, the patients response appears to be limited primarily by the number of $\mathrm{T}$ responder cells.

Effect of removing adherent cells from the stimulator population. Adherent non-T cells have been described as poor stimulators in the autologous MLR and removal of these cells from the non-T population reportedly enhances the reaction in normal donors (33). To assess the possibility that an excess of adherent cells in our patients prevented detection of autoreactive lymphocytes, nonrosetting cells from 10 patients were depleted of adherent cells and the recovered nonadherent cells were tested as stimulators in the autologous MLR. As shown in Table II, removal of adherent cells enhanced the autologous MLR in most patients. However, with the exception of patient 39, whose cells stimulated normally before removal of adherent cells, this procedure resulted in only modest increases in responsiveness and failed to restore autologous stimulation to normal levels.

Cellular basis of the impaired autologous MLR. To 
TABLE II

Effect of Removing Adherent Cells on Stimulation in the Autologous MLR

\begin{tabular}{ccc}
\hline & \multicolumn{2}{c}{ Stimulation by: } \\
\cline { 2 - 3 } Patient No. & Nonrosetting cells & $\begin{array}{c}\text { Nonrosetting cells } \\
\text { depleted of } \\
\text { adherent cells }\end{array}$ \\
\hline \multicolumn{3}{c}{$c p m$} \\
7 & $1,063 \pm 198$ & $2,303 \pm 179$ \\
8 & $881 \pm 46$ & $1,751 \pm 148$ \\
24 & $2,743 \pm 164$ & $3,756 \pm 310$ \\
36 & $1,845 \pm 105$ & $1,231 \pm 213$ \\
44 & $15,334 \pm 1,243$ & $24,491 \pm 1,868$ \\
45 & $259 \pm 62$ & $2,137 \pm 190$ \\
47 & $5,593 \pm 618$ & $6,950 \pm 635$ \\
51 & $3,250 \pm 410$ & $4,179 \pm 557$ \\
58 & $3,285 \pm 163$ & $4,014 \pm 536$ \\
& $1,577 \pm 132$ & $3,233 \pm 384$ \\
\hline
\end{tabular}

Non-T cells from 10 patients were either used directly as stimulators in the autologous MLR or depleted of adherent cells by incubation in plastic petri dishes before culture. Reactivity was measured by the incorporation of $\left[{ }^{3} \mathrm{H}\right]$ thymidine into DNA with results presented as mean $\pm \mathrm{SE}$ for triplicate cultures.

determine whether the impaired autologous MLR was due to a defect of responder cells, stimulator cells, or both, two patients in remission and their healthy HLAidentical siblings were studied. In these studies, $T$ lymphocytes from a patient, an HLA-A, B, DR-identical sibling, and an unrelated healthy volunteer were cultured with non-T lymphocytes from each of these three subjects. As shown in Table III, autologous MLR were diminished in patients but normal in their healthy siblings. $\mathrm{T}$ cells from healthy siblings responded normally to the non-T cells of affected siblings, indicating that there is no defect in the capacity of non-T cells of these patients to stimulate HLA-identical cells. On the other hand, both patients failed to respond both to their own non- $T$ cells and to their sibling's non- $T$ cells, suggesting again that a defective responder $T$ cell population is responsible for the failure of these patients to mount an autologous MLR.

Possible explanations for the failure of patients' $T$ cells to react to autologous non-T cells included $(a)$ failure of autoreactive $\mathrm{T}$ cells to rosette with sheep erythrocytes; $(b)$ interference of $T$ cell function by membrane-bound plasma factors; $(c)$ presence of suppressor cells that inhibit the autologous MLR; and $(d)$ reduction in number and/or function of autoreactive $T$ cells. The possibility that autoreactive $T$ cells remained in the nonrosetting fraction seemed unlikely because PBML were as unresponsive in the autologous MLR as $T$ cell-enriched fractions from the same patients (data not shown). Others have reported that overnight incubation of Hodgkin's patients lymphocytes in fetal calf serum enhanced rosetting with sheep erythrocytes (47), but this procedure did not increase responses by $T$ cells in the autologous MLR. We further examined this question by separating $T$ cells from non-T cells using a method other than rosetting with sheep erythrocytes. In five patients $T$ cells were separated from non-T cells on the basis of binding to plastic petri dishes coated with anti-Ig and were then tested in the autologous MLR. The results (Table IV) indicate that with either positive selection or negative selection for $\mathrm{T}$ cells, patient $\mathrm{T}$ cells mounted diminished responses in the autologous MLR.

In an effort to remove any membrane-bound blocking

TABLE III

Cellular Basis of the Impaired Autologous MLR in Hodgkin's Disease

\begin{tabular}{lccc}
\hline & \multicolumn{3}{c}{ Response by stimulator non-T cells } \\
\cline { 2 - 4 } \multicolumn{1}{c}{ Responder T cells } & Patient A & Healthy sibling of A & Unrelated donor 1 \\
\hline Hodgkin's patient A & $1,611 \pm 192$ & $c p m$ & \\
Healthy sibling of A & $29,915 \pm 3,125$ & $22,891 \pm 2,450$ & $47,510 \pm 4,264$ \\
Unrelated donor 1 & $36,159 \pm 4,029$ & $39,670 \pm 4,036$ & $19,488 \pm 2,090$ \\
& Patient B & Healthy sibling of B* & Unrelated donor 2 \\
\cline { 2 - 2 } & $702 \pm 95$ & $1,140 \pm 146$ & $34,566 \pm 2,822$ \\
Hodgkin's patient B & $10,466 \pm 907$ & $8,572 \pm 1,410$ & $51,321 \pm 4,398$ \\
Healthy sibling of B & $18,595 \pm 2,335$ & $39,314 \pm 3,589$ & $13,286 \pm 1,655$ \\
Unrelated donor 2 & & & \\
\hline
\end{tabular}

Healthy siblings were HLA-A, B, C and DR-identical to patients A (A2,Aw26/B8, $\mathrm{Bw50/Cw6/DRw3,DRw6)} \mathrm{or} \mathrm{B} \mathrm{(A2,A24/B17,35/Cw3/DRwl,5).} \mathrm{Patients} \mathrm{A} \mathrm{and} \mathrm{B} \mathrm{were}$ unrelated and were in remission, 4 and $7 \mathrm{yr}$ after treatment, respectively. Results represent the mean $\pm \mathrm{SE}$ of triplicate cultures. 
TABLE IV

Effects of Method of Cell Isolation on Autologous MLR

\begin{tabular}{ll}
\hline & \multicolumn{2}{c}{ Response by: } \\
\cline { 2 - 2 } Patient No. & E rosette $(+)$ lymphocytes $\quad \operatorname{Ig}(-)$ lymphocytes \\
\hline
\end{tabular}

$c p m$

$\begin{array}{rrc}1 & 1,063 \pm 145 & 1,822 \pm 206 \\ 40 & 3,840 \pm 906 & 4,450 \pm 564 \\ 51 & 3,285 \pm 506 & 3,476 \pm 717 \\ 57 & 342 \pm 101 & 272 \pm 38 \\ 63 & 6,115 \pm 742 & 8,216 \pm 1,010\end{array}$

Before culture in autologous MLR, T cells were separated from non-T cells either on the basis of rosetting with sheep erythrocytes ( $E$ rosette $(+)$ lymphocytes) or on the basis of failure to bind plastic petri dishes coated with anti-Ig (Ig (-) lymphocytes). Results represent the mean $\pm \mathrm{SE}$ responses of triplicate cultures.

factors, $\mathrm{T}$ cells from four treated and two untreated patients were incubated in medium for $2-24 \mathrm{~h}$ at $37^{\circ} \mathrm{C}$. The cells were then washed and tested in the autologous MLR. This procedure failed to produce an autologous MLR response in our patients (data not shown). In additional experiments, substitution of plasma from patients for pooled $A B$ serum did not inhibit the autologous MLR of normal donors.

Finally, to test the possibility that suppressor cells were responsible for the diminished autologous MLR of Hodgkin's patients, the autologous MLR of a healthy HLA-identical sibling was performed in the presence and absence of lymphocytes from an affected sibling. As shown in Table $\mathrm{V}$, the addition of either unseparated PBML or fractions enriched for $T$ or non-T cells did not affect the autologous MLR of the healthy sibling. Cells that had been irradiated with 1,500 rad also failed to affect the autologous MLR of the healthy siblings. These results suggest that it is unlikely that suppressor cells are responsible for the defect of autologous MLR in the patient studied.

\section{DISCUSSION}

These data demonstrate that the $\mathrm{T}$ cells of patients with Hodgkin's disease respond poorly to autologous non-T cells. Impairment of the autologous MLR apparently precedes treatment because untreated patients have diminished responses, and the defect in untreated patients could not be distinguished from the defect in treated patients. Because treated patients also have depressed autologous MLR, therapy either fails to reverse a defect associated with disease or induces a second defect, which persists after cessation of treatment. All treated patients had received one of several forms of radiotherapy and many received total
TABLE V

Failure of Lymphocytes from a Hodgkin's Patient to Suppress the Autologous MLR of a Healthy HLA-identical Sibling

\begin{tabular}{ccc}
\hline $1 \times 10^{5}$ & $5 \times 10^{4}$ & Response by \\
stimulator & $\begin{array}{c}\text { added } \\
\text { cells }\end{array}$ & $\begin{array}{c}\mathrm{T} \text { cells sibling } \\
\mathrm{T} \text { cells }\end{array}$ \\
\hline & & $c p m$
\end{tabular}

$\begin{array}{lll}\text { Sibling } & \text { None } & 20,506 \pm 2566 \\ \text { Sibling } & \text { Patient T } & 22,161 \pm 1810 \\ \text { Sibling } & \text { Patient T (irradiated)* } & 19,630 \pm 1224 \\ \text { Sibling } & \text { Patient non-T } & 32,755 \pm 3058 \\ \text { Sibling } & \text { Patient non-T (irradiated)* } & 34,101 \pm 4415 \\ & & 22,509 \pm 1520 \\ \text { Patient } & \text { None } & 21,748 \pm 1743 \\ \text { Patient } & \text { Patient T } & 22,562 \pm 2618 \\ \text { Patient } & \text { Patient T (irradiated)* } & 35,243 \pm 4005 \\ \text { Patient } & \text { Patient non-T } & 36,156 \pm 3329 \\ \text { Patient } & \text { Patient non-T (irradiated)* }\end{array}$

$5 \times 10^{4}$ responder $\mathrm{T}$ cells of a healthy donor were challenged with $1 \times 10^{5}$ autologous non-T cells in the presence of $T$ or non-T cells from his HLA-A, B, DR-identical sibling with Hodgkin's disease. Results represent the mean $\pm S E$ responses of triplicate cultures. Patient is patient A in Table II. A in Table II.

* 1,500 rad.

nodal irradiation (TNI), which has significant longterm effects on the functions of peripheral blood lymphocytes (48). Indeed, TNI prolongs the survival of histoincompatible organ allografts in rats (49), suppresses experimental autoimmune disease in mice (50), and is currently under investigation as an immunotherapeutic modality in man. A few patients in this study who were tested 10 yr or more after treatment had normal autologous MLR reactivity, suggesting that recovery of this response may eventually occur. Determination of the precise effects of radiation therapy on the autologous MLR require studies of patients with disorders other than Hodgkin's disease who have normal autologous MLR before treatment. In this regard, patients with intractible rheumatoid arthritis are currently undergoing a clinical trial of TNI at Stanford University. Studies of these patients before and after treatment indicate that TNI acutely inhibits both the autologous and allogeneic MLR, but a longer follow-up period is required to determine the duration of these effects. ${ }^{2}$

A number of potential explanations for the impaired autologous MLR in Hodgkin's disease, such as increased sensitivity of stimulator cells to X-irradiation, poor viability of stimulator or responder cells, dissociation of thymidine uptake from blast transformation, and accelerated or delayed kinetics of response, were

${ }^{2}$ Engleman, E. G., C. Benike, B. Kotzin, and S. Strober. Unpublished observations. 
ruled out experimentally. Increases in the number of responder $T$ cells or depletion of adherent cells from the non- $T$ cell stimulator population enhanced the autologous MLR in some patients, indicating that these patients are not totally devoid of autoreactive cells. However, these maneuvers failed to restore responses to normal levels and, therefore, alternative explanations were sought for the defect.

The nature of the defect in two patients who had been treated previously was clarified by performing reciprocal mixing experiments between patients and their healthy HLA-identical siblings. A similar approach has been used by other investigators to demonstrate that the diminished autologous MLR in patients with systemic lupus erythematosus is in some cases a consequence of defective stimulator cells (51) and in other cases a consequence of defective responder cells (52). A defect of autologous stimulator cells has been described in patients with mononucleosis (41) and chronic lymphocytic leukemia $(53,54)$. The defect in Hodgkin's disease appears to be in the responder T cell population rather than in the stimulator cells. In each of two cases, the T cells of healthy HLA-identical siblings mounted vigorous proliferative responses both to autologous and affected siblings' non-T cells. Patients' $T$ cells, however, failed to respond both to autologous and their healthy siblings' non-T cells. In a separate experiment cells from one patient who failed to respond in an autologous MLR did not inhibit the response of a healthy HLA-identical sibling, suggesting that this patient's lack of response is not due to suppressor cells. This finding does not rule out the possibility that suppressor cells might play a role in the diminished autologous MLR of other patients. Nonetheless, the simplest interpretation of these data is that the population of autoreactive $T$ lymphocytes, normally present in peripheral blood, is reduced in number or dysfunctional in patients with Hodgkin's disease.

It is evident from these studies that impairment of the autologous MLR is both more common and more pronounced than impairment of the allogeneic MLR in Hodgkin's patients. Thus, many patients who respond vigorously to allogeneic cells fail to respond to autologous non- $T$ cells. These results are consistent with the suggestion of others $(38,41)$ that the interaction between $T$ and autologous non- $T$ cells involves different mechanisms than the interaction between $T$ and allogeneic non-T cells. This difference might be due to incompletely overlapping $\mathrm{T}$ cell subpopulations, some responsive exclusively to allogeneic or autologous non-T cells and others responsive to both. In patients with Hodgkin's disease the T cell subpopulation responsive to allogeneic cells is at least partially functional. Moreover, the modest reduction in allogeneic MLR commonly observed in these patients may be explained by the absence of autoreactive $\mathrm{T}$ cells. In those patients with more pronounced impairment of alloreactivity, MLR suppressor cells may also be present $(17,29-31)$.

It is possible that the loss of autologous MLR and the pathogenesis of Hodgkin's disease are related. In this regard, the observations of van de Stouwe et al. (37) are of particular interest. These investigators observed that the autologous reaction could serve as a proliferative stimulus for specific cytotoxic lymphocyte generation. Thus, heat-treated allogeneic lymphocytes that alone did not stimulate proliferation or cytotoxic $T$ cell generation in MLR reactions produced specific cytotoxic cells when added to the autologous system. Other investigators have found that lymphocytes from normal individuals sensitized to HLA-identical leukemic cells could, in the presence of an allogeneic proliferative stimulus, differentiate into cells specifically cytotoxic to leukemic cells (55). In vivo, the autologous MLR may provide the stimulus needed for the generation of cytotoxic lymphocytes against autologous neoplastic or virally infected cells. Conceivably, Hodgkin's disease might result from a failure of this protective mechanism.

\section{ACKNOWLEDGMENTS}

We thank Dr. Carl Grumet of Stanford University for HLA-A, B, C, and DR typing of two patients and their families. We thank Marion Batey and Linda Siri for expert technical assistance.

This work was supported in part by grants CA24607 and CA05838 from the National Institutes of Health and an institutional grant from the American Cancer Society.

\section{REFERENCES}

1. Chase, M. W. 1966. Delayed type hypersensitivity and the immunology of Hodgkin's disease, with a parallel examination of sarcoidosis. Cancer Res. 26: 1097-1120.

2. Brown, R. S., B. A. Haynes, H. T. Foley, H. A. Godwin, C. W. Berard, and P. P. Carbone. 1967. Hodgkin's disease: immunologic, clinical and histologic features of 50 untreated patients. Ann. Intern. Med. 67: 291-296.

3. Schier, W. W., A. P. Roth, G. Ostroff, and M. H. Schrift. 1956. Hodgkin's disease and immunity. Am. J. Med. 20: $94-99$.

4. Sokal, J. E., and M. Primikirios. 1969. The delayed skin test response to Hodgkin's disease and lymphosarcoma. Cancer(Phila.). 14: 597-607.

5. Aisenberg, A. C. 1962 . Studies on delayed hypersensitivity in Hodgkin's disease.J. Clin. Invest. 41: 1964-1970.

6. Young, R. C., M. P. Corder, H. A. Haynes, and V. T. DeVita. 1973. Delayed hypersensitivity in Hogkin's disease. A study of 103 patients. Am. J. Med. 52: 63-72.

7. Eltringham, J. R., and H. S. Kaplan. 1973. Impaired delayed hypersensitivity responses in 154 patients with untreated Hodgkin's disease. Natl. Cancer Inst. Monogr. 36: $107-115$.

8. Green, I., and P. F. Corso. 1959. A study of skin homografting in patients with lymphomas. Blood. 14: 235-245.

9. Kelly, W. D., D. L. Lamb, R. L. Varco, and R. A. Good. 1960. An investigation of Hodgkin's disease with respect 
to the problem of homotransplantation. Ann. N. Y. Acad. Sci. 87: 187-202.

10. Miller, D. G., J. G. Lizardo, and R. K. Snyderman. 1969. Homolygous and heterologous skin transplantation in patients with lymphomatous disease. J. Natl. Cancer Inst. 26: $569-583$.

11. Casazza, A. R., C. P. Duvall, and P. P. Carbone. 1966. Summary of infectious complications occurring in patients with Hodgkin's disease. Cancer Res. 26: 1290-1296.

12. Goffinet, D. R., E. J. Glatstein, and T. C. Merigan. 1972. Herpes Zoster varicella infections and lymphoma. Ann. Intern. Med. 76: 235-240.

13. Aisenberg, A. C. 1967. Quantitative estimation of the reactivity of normal and Hodgkin's disease lymphocytes with thymidine- $2{ }^{14} \mathrm{C}$. Nature (Lond.). 205: 1233-1235.

14. Gaines, J. D., A. Gilmer, and J. S. Remington. 1973. Deficiency of antigen recognition in Hodgkin's disease. Natl. Cancer Inst. Monogr. 36: 117-121.

15. DeGast, G. C., M. R. Halie, and H. O. Nieweg. 1975. Immunological responsiveness against two primary antigens in untreated patients with Hodgkin's disease. Eur. J. Cancer. 11: 217-224.

16. Bjorkolm, M., G. Holm, H. Mellstedt, and D. Pettersson. 1976. Immunological capacity of lymphocytes from untreated patients with Hodgkin's disease evaluated in mixed lymphocyte culture. Clin. Exp. Immunol. 22: 373-377.

17. Twomey, J. J., A. H. Laughter, S. Farrow, and C. C. Douglass. 1975. Hodgkin's disease: an immunodepleting and immunosuppressive disorder. J. Clin. Invest. 56: 467-475.

18. Bobrove, A. M., Z. Fuks, S. Strober, and H. S. Kaplan. 1975. Quantitation of T and B lymphocytes and cellular immune function in Hodgkin's disease. Cancer (Phila.). 36: $169-179$.

19. Hersh, E. M., and J. J. Oppenheim. 1965. Impaired in vitro transformation in Hodgkin's disease. N. Engl. J. Med. 273: 1006-1012.

20. Trubowitz, S., B. Masek, and A. Del Rosario. 1966. Lymphocyte response to phytohemagluttinin in Hodgkin's disease. Lymphatic leukemia, and lymphosarcoma. Cancer (Phila.). 19: 2019-20230.

21. Han, T., and J. E. Sokal. 1970. Lymphocyte response to phytohemagluttinin and Hodgkin's disease. Am. J. Med. 48: 728-734.

22. Corder, M. P., R. C. Young, R. S. Brown, and V. T. DeVita. 1972. Phytohemagluttinin induced lymphocyte transformation. The relationship to prognosis of Hodgkin's disease. Blood. 39: 595-601.

23. Matchett, K. M., A. T. Huang, and W. B. Kremer. 1963. Impaired lymphocyte transformation in Hodgkin's disease. Evidence for depletion of circulating T lymphocytes. J. Clin. Invest. 52: 1908-1917.

24. Gajl-Peczalska, K. J., J. A. Hausen, C. D. Bloomfield, and R. A. Good. 1973. B lymphocytes in untreated patients with malignant lymphoma and Hodgkin's disease. J. Clin. Invest. 52: 3064-3073.

25. Levy, R., and H. S. Kaplan. 1974. Impaired lymphocyte function in untreated Hodgkin's disease. N. Engl. J. Med. 290: $181-186$.

26. Faughet, G. B. 1975. Quantitation of Immunocompetence in Hodgkin's disease. J. Clin. Invest. 56: 951-957.

27. Ziegler, J. B., P. Hausen, and R. Penny. 1975. Intrinsic lymphocyte defect in Hodgkin's disease: analysis of the phytohemagluttinin in dose response. Clin. Immunol. Immunopathol. 3: 451-460.

28. Goodwin, J. S., R. P. Messner, A. D. Bankhurst, G. T.
Peake, J. Saiki, and R. C. Williams, Jr. 1977. Prostaglandin-producing suppressor cells in Hodgkin's disease. N. Engl. J. Med. 297: 963-968.

29. Hillinger, S. M., and G. P. Herzig. 1978. Impaired cell mediated immunity in Hodgkin's disease mediated by suppressor lymphocytes and monocytes. J. Clin. Invest. 61: 1620-1627.

30. Schechter, G. P., and S. Frances. 1978. Monocyte mediated inhibition of lymphocyte blastogenesis in Hodgkin's disease. Blood. 52: 261-271.

31. Engleman, E. G., C. Benike, R. T. Hoppe, and H. S. Kaplan. 1979. Suppressor cells of the mixed lymphocyte reaction in patients with Hodgkin's disease. Transplant. Proc. 11: 1827.

32. Opelz, G., K. Masahiro, M. Takasugi, and P. J. Terasaki. 1975. Autologous stimulation of human lymphocyte subpopulations. J. Exp. Med. 142: 1327-1333.

33. Kuntz, M. M., J. B. Innes, and M. E. Weksler. 1976. Lymphocyte transformation induced by autologous cells. IV. Human $T$ lymphocyte proliferation induced by autologous or allogeneic non-T lymphocytes. J. Exp. Med. 143: $1042-1054$.

34. Takasugi, M., M. Kiuchi, and G. Opelz. 1977. Lymphocyte interactions in autologous and allogeneic reactions. Transplant. Proc. 9: 789-792.

35. Beale, M. G., R. P. Macdermott, M. C. Stacey, G. S. Nash, B. H. Hahn, M. V. Seiden, S. L. Burkholder Jacobs, and L. S. Pletscher Loewenstein. 1979. Stimulating cell types in the autologous mixed leukocyte reaction in man. J. Immunol. 124: 227-232.

36. Weksler, M. E., and R. Kozak. 1977. Lymphocyte transformation induced by autologous cells. V. Generation of immunologic memory and specificity during the autologous mixed lymphocyte reaction. J. Exp. Med. 146: 1833-1838.

37. Van de Stouwe, R. A., H. G. Kunkel, J. P. Halper, and M. E. Weksler. 1977. Autologous mixed lymphocyte culture reactions and generation of cytotoxic T cells. J. Exp. Med. 48: $1809-1814$.

38. Hausman, P. B., and J. D. Stobo. 1979. Specificity and function of a human autologous reactive T cell. J. Exp. Med. 149: 1537-1542.

39. C. Moody, J. Innes, B. Casazza, M. M. Kuntz, Y. T. Kim, and M. E. Weksler. 1979. Autologous mixed lymphocyte reactions, autoimmunity, and the generation of suppressor cells. Clin. Res. 27: 473A. (Abstr.)

40. Smith, J. B., and K. P. Knowlton. 1979. Activation of Suppressor T cells in human autologous immune lymphocyte culture. J. Immunol. 123: 419-422.

41. Sakane, T., and I. Green. 1979. Specificity and suppressor function of human $T$ cells responsive to autologous non- $T$ cells. J. Immunol. 123: 583-589.

42. Boyum, A. 1968. Isolation of mononuclear cells and granulocytes from human blood. Scan. J. Clin. Lab. Invest. 21(Suppl. 97): 77-89.

43. Gmelig-Meyling, F., and R. E. Ballieux. 1977. Simplified procedure for the separation of human $\mathrm{T}$ and non-T cells. Vox Sang. 33: 5-8.

44. Engleman, E. G., and H. O. McDevitt. 1978. A suppressor $T$ cell of the mixed lymphocyte reaction specific for the HLA-D region in man. J. Clin. Invest. 61: 828-838.

45. Yam, L. T., C. Y. Li, and W. H. Crosby. 1971. Cytochemical identification of monocytes and granulocytes. Am.J. Clin. Pathol. 55: 283-290.

46. Wysocki, L. J., and V. L. Sato. 1978. “Panning” for lymphocytes: A method for cell selection. Proc. Natl. Acad. Sci. U. S. A. 75: 2844-2848. 
47. Fuks, Z., S. Strober, D. P. King, and H. S. Kaplan. 1976. Reversal of cell surface abnormalities of $\mathrm{T}$ lymphocytes in Hodgkin's disease after in vitro incubation in fetal sera. J. Immunol. 117: 1331-1335.

48. Fuks, Z., S. Strober, A. M. Bobrove, T. Sasazuki, A. McMichael, and H. S. Kaplan. 1976. Long term effects of radiation on $\mathrm{T}$ and $\mathrm{B}$ lymphocytes in peripheral blood of patients with Hodgkin's disease. J. Clin. Invest. 58: 803-814.

49. Slavin, S., B. Reitz, C. P. Bieber, H. S. Kaplan, and S. Strober. 1978. Transplantation tolerance in adult rats using total lymphoid irradiation: permanent survival of skin, heart, and marrow allografts. J. Exp. Med. 147: 700-707.

50. Kotzin, B. L., and S. Strober. 1979. Reversal of NZB/ NZW disease with total lymphoid irradiation.J. Exp. Med. 150: $371-378$.

51. Kuntz, M. M., J. B. Inez, and M. E. Weksler. 1979. The cellular basis of the impaired autologous mixed lympho- cyte reaction in patients with systemic lupus erythematosus. J. Clin. Invest. 63: 151-153.

52. Sakane, T., A. D. Steinberg, and I. Green. 1978. Failure of autologous mixed lymphocyte reactions between $\mathrm{T}$ and non-T cells in patients with systemic lupus erythematosus. Proc. Natl. Acad. Sci. U. S. A. 75: 3464-3468.

53. Kuntz, M. M., J. B. Innes, and M. E. Weksler. 1976. Impaired immune surveillance in chronic lymphocytic leukemia (CLL) and systemic lupus erythematosus (SLE). Clin. Res. 24: 448A. (Abstr.)

54. Smith, J. B., K. P. Knowlton, and L. S. Koons. 1977. Immunologic studies in chronic lymphocytic leukemia: defective stimulation of $T$ cell proliferation in autologous mixed lymphocyte culture. J. Natl. Cancer Inst. 58: 579-585.

55. Sondel, P. M., C. O'Brien, L. Porter, S. F. Schlossman, and L. Chess. 1976. Cell mediated destruction of human leukemic cells by MHC identical lymphocytes: requirements for a proliferative trigger in vitro. J. Immunol. 117: 2197-3002. 